\title{
Formaldehyde content of milk. 2. Cows fed on grass silage preserved with formaldehyde-containing additive and on formaldehyde-treated urea
}

\author{
LIISA SYRJÄLÄ-QVIST and JOUKO SETÄLÄ \\ Department of Animal Husbandry, University of Helsinki, \\ SF-00710 Helsinki 71
}

\begin{abstract}
In two different experiments silages prepared with formaldehyde-containing additives were fed to cows with and without formaldehyde-treated urea, and formaldehyde was determined on both the silage and the milk. The silage additive contained $20 \% \mathrm{HCHO}$ and $30 \% 80 \%$ acetic acid and it was used at the rate of $51 /$ ton raw material. The treatment levels of urea were $1.4-1.5 \mathrm{~g} \mathrm{HCHO} / 100 \mathrm{~g}$ urea. Twenty-two Friesian cows were used in Experiment 1 and 20 Ayrshire cows in Experiment 2. In Both experiments they were divided into two groups, one of which had silage as the only source of formaldehyde and the other both silage and HCHO-treated urea. Exp. 1 lasted 18 weeks and Exp. 213 weeks. The average daily milk yield in Exp. 1 was $14.2 \mathrm{~kg}$ and in Exp. 2 it was $22.8 \mathrm{~kg}$ FCM.

When the experiments started at least 4 months had elapsed from the preparation of the silages. In Exp. 1 the silage contained on average $13.0 \mathrm{mg} \mathrm{HCHO} / \mathrm{kg}(10-16 \mathrm{mg} / \mathrm{kg}, \mathrm{n}=5)$ and in Exp. 2 it contained 64 $\mathrm{mg} \mathrm{HCHO} / \mathrm{kg}(45-90 \mathrm{mg} / \mathrm{kg}, \mathrm{n}=8)$. Judged by the fermentation criteria both silages were of good quality, but according to organoleptic tests the quality of the silage was better in Exp. 1 than in Exp. 2.

In Exp. 1 the cows received $\mathrm{HCHO}$ from the silage at the average rate of $0.13 \mathrm{~g} /$ day and one group also received $2.01 \mathrm{~g} \mathrm{HCHO} /$ day from the treated urea (altogether $2.14 \mathrm{~g} /$ day). Formaldehyde was found in the milk of four cows on the latter diet but in only one milk sample from three of them and in two samples from one. The $\mathrm{HCHO}$ content of these samples was $0.2-0.3 \mathrm{mg} / \mathrm{l}$.

In Exp. 2 the cows in the two groups received $\mathrm{HCHO}$ from the silage at the average rates of $1.47 \mathrm{~g}$ and $1.58 \mathrm{~g} /$ day. In addition those in the latter group received $1.29 \mathrm{~g} \mathrm{HCHO}$ from the HCHO-urea (altogether $2.87 \mathrm{~g} /$ day). The average formaldehyde content of the milk in the former group was $0.3 \mathrm{mg} / 1(0-0.7 \mathrm{mg} / \mathrm{l})$ and in the HCHO-urea group $0.6 \mathrm{mg} / 1(0.3-1.0 \mathrm{mg} / \mathrm{l})$. When the only source of formaldehyde was silage, there was a highly significant positive correlation between the $\mathrm{HCHO}$ content of the diet and that of milk, but when the cows received formaldehyde from both silage and HCHO-urea, the correlation was not significant. It thus appears that formaldehyde is transferred more easily to milk from silage than from $\mathrm{HCHO}$ treated urea.
\end{abstract}

\section{Introduction}

The use of formaldehyde-containing silage preservatives has increased in the 1970s. The recommended amounts of these preservatives, 4-6 l/ton grass, have, at least in Finland, generally been equivalent to $900-1300 \mathrm{mg}$ of free formaldehyde/ $\mathrm{kg}$ grass at the beginning of ensiling. Although the formal- 
dehyde disappears more or less during ensiling, it has been showed, that it can be present in mature silage and can affect the formaldehyde content of the milk (BECK and GROSS 1973, HONIG and ROHR 1973, RAURAMAA and KREULA 1977).

The purpose of this study was to examine the formaldehyde content of silages prepared with formaldehyde-containing additives on the scale used in farming, and the formaldehyde content of milk from cows fed on those silages. Together with the silages, some cows also received formaldehydetreated urea (SETÄLÄ and SYRJÄLÄ-QVIST $1982 \mathrm{a}, \mathrm{b}, \mathrm{c}$ ). This study comprises two separate experiments, whose procedures are explained in more detail in other papers (SETÄLÄ and SYRJÄLÄ-QVIST 1982 d, Exp. 1, SETÄLÄ et al. 1982, Exp. 2).

\section{Experimental procedures}

Experiment 1 was performed with 22 Friesian dairy cows divided into two groups:

1) Group given untreated urea

2) Group given formaldehyde-urea, $1.5 \mathrm{~g} \mathrm{HCHO} / 100 \mathrm{~g}$

urea (SETÄLÄ and SYRJÄLÄ-QVIST $1982 \mathrm{a}, \mathrm{b}, \mathrm{c}$ )

The average daily ration of a cow consisted of $10 \mathrm{~kg}$ grass silage, $10 \mathrm{~kg}$ hay, $4.5 \mathrm{~kg}$ ground barley-oats mixture and $122-134 \mathrm{~g}$ urea adjusted according to the nutrient requirement.

The silage was pre-wilted, with a dry matter content of $22.7 \%$, and preserved with formaldehyde-containing additive, Viher solution $(20 \%$ formaldehyde and $30 \% 80-\%$ acetic acid) at the rate of $51 /$ ton raw material. On average, the dry matter of the silage contained crude protein $15.3 \%$, crude fibre $33.0 \%$, sugars $1.6 \%$ and $\mathrm{NH}_{3}-\mathrm{N} 0.17 \%$. The $\mathrm{pH}$ was 4.0 and the quality was good.

Urea was mixed with the concentrate, its proportion being $2.5-3.0 \%$. The crude protein content of the rations was $14.0-14.8 \%$ of dry matter.

Experiment 1 lasted 18 weeks, including the 8-week test period (for details, see SETÄLÄ and SYRJÄLÄ-QVIST 1982 d). The average daily milk yield during the test period in the group given untreated urea was $13.7 \mathrm{~kg}$ and in the group given formaldehyde-urea $14.6 \mathrm{~kg}$.

Experiment 2 was performed with 20 high-production Ayrshire cows, of which 7 cows received no protein supplements, 7 cows received rape seed meal as supplement and 6 cows received formaldehyde-urea $(1.5 \mathrm{~g} \mathrm{HCHO} /$ $100 \mathrm{~g}$ urea) as supplement. For this study they were grouped as follows:

1) Group given no urea (14 cows)

2) Group given formaldehyde urea (6 cows)

The average daily ration consisted of $23.0-25.4 \mathrm{~kg}$ grass silage, $1.6 \mathrm{~kg}$ hay, 7.8-9.2 kg ground barley-oats mixture, adjusted according to the nutrient requirements, with no protein supplement or with $600 \mathrm{~g}$ rape seed meal or $118 \mathrm{~g}$ formaldehyde urea. 
The silage was fresh-cut silage, with a dry matter content of $22.3 \%$, and preserved as in experiment 1 with Viher solution. On average, the dry matter of the silage contained crude protein $14,9 \%$, crude fibre $32,2 \%$, sugars 3.2 $\%$ and $\mathrm{NH}_{3}-\mathrm{N} 0.14 \%$. Its $\mathrm{pH}$ was 3.8 .

Urea was given with the concentrate, its proportion being 1.1-2.2\%. The crude protein content of the ration was $12.4-15.2 \%$ of dry matter.

Experiment 2 lasted 13 week including the 8-week test period (for details, see SETÄLÄ et al. 1982). The average daily milk yields during the test period in the group given no urea was $24.6 \mathrm{~kg}$ and in the formaldehyde-urea group $20.9 \mathrm{~kg}$.

The formaldehyde content of the silage, formaldehyde-urea and milk was measured on samples taken before the test period and every second (Exp. 1) or every third (Exp. 2) week during the test period. The determinations were made by the method of BECK and GROSS (1973), with slight modification (ANON 1975, see also KREULA and RAURAMAA (1976).

\section{Results}

Experiment 1. The formaldehyde content of the silage averaged $13 \mathrm{mg} / \mathrm{kg}$ $(10-16 \mathrm{mg} / \mathrm{kg}, \mathrm{n}=5)$. The amounts of formaldehyde received by different diets were as follows:

\begin{tabular}{|c|c|c|}
\hline \multirow{2}{*}{$\begin{array}{l}\text { Source } \\
\text { of } \mathrm{HCHO}\end{array}$} & \multicolumn{2}{|c|}{ Supply of $\mathrm{HCHO}, \mathrm{g} /$ cow/day } \\
\hline & $\begin{array}{l}\text { Untreated urea } \\
\text { diet }\end{array}$ & $\begin{array}{l}\text { Formaldehyde-urea } \\
\text { diet }\end{array}$ \\
\hline Silage & 0.13 & 0.13 \\
\hline Urea & - & $2.01(1.66-2.26)$ \\
\hline Total & 0.13 & 2.14 \\
\hline
\end{tabular}

Formaldehyde was found in the milk of only four of the cows on the formaldehyde-urea diet, but not on each of the five sampling times. It was present in only one milk sample from three of these four cows and in two samples from one. In these samples the formaldehyde content was $0.2-0.3$ $\mathrm{mg} / \mathrm{l}$ milk. No formaldehyde was found in the milk of the cows on the untreated urea diet.

Experiment 2. The formaldehyde content of the silage averaged $64 \mathrm{mg} / \mathrm{kg}$ $(45-90 \mathrm{mg} / \mathrm{kg}, \mathrm{n}=8)$. The amounts of formaldehyde received by the animals on the different diets were as follows:

\begin{tabular}{lcc} 
Source & \multicolumn{2}{c}{ Supply of $\mathrm{HCHO}, \mathrm{g} / \mathrm{cow} / \mathrm{day}$} \\
of $\mathrm{HCHO}$ & Diet without urea & Diet with formaldehyde-urea \\
Silage & $1.47(0.99-1.84)$ & $1.58(1.12-1.89)$ \\
Urea & - & $1.29(1.01-2.31)$ \\
\hline \multicolumn{1}{c}{ Total } & 1.47 & 2.87
\end{tabular}

There were large variations in the formaldehyde content of the milk. When the diet contained no urea, or when the only source of formaldehyde was the silage, the formaldehyde content of the milk averaged $0.3 \mathrm{mg} / \mathrm{l}$, 
ranging from 0 to $0.7 \mathrm{mg} / \mathrm{l}$. On the formaldehyde-urea diet, or when the animals received formaldehyde from both the silage (55\%) and the urea (45 $\%$ ), the formaldehyde content of the milk averaged $0.6 \mathrm{mg} / \mathrm{l}$, ranging from 0.3 to $1.0 \mathrm{mg} / \mathrm{l}$.

\section{Discussion}

\section{Formaldehyde content of silage}

The formaldehyde content of the silage in Exp. 2 was about 2 $\frac{1}{2}$ times as high as in Exp. 1., although the levels of application were the same in the two cases. The amount of Viher solution, about $5 \mathrm{l} /$ ton grass, added during preparation of the silage, corresponded to about $1000 \mathrm{mg}$ formaldehyde $/ \mathrm{kg}$ grass. The proportion remaining in the mature silage was only $1.0-1.6 \%$ in Exp. 1 and 4.5-9.0 \% in Exp. 2. In both experiments the first formaldehyde measurements were made on the silage when at least 4 months had elapsed from their preparation and the last ones $2-3$ months later.

The reason for the different formaldehyde levels in the silages is difficult to know, because of the many differences in the way in which they were prepared, for instance, in the pre-treatment of the raw material, the form of the silo, the care taken in preparation. According to the organoleptic assessments (based on colour, odour etc.) the quality of the silage in Exp. 1 was much better than that of the silage in Exp. 2, although according to the fermentation criteria the quality of the two silages was the same, and quite good (table 1). So the poorer organoleptic quality of the silage in Exp. 2 may reflect the higher residue of formaldehyde.

The formaldehyde content of silage has varied in different studies. HONIG and ROHR (1973) used 900-1860 mg formaldehyde per $\mathrm{kg}$ raw

Table 1 . The mean chemical composition and the quality criteria of the silages.

\begin{tabular}{lcc}
\hline & In Exp. 1 & In Exp. 2 \\
\hline Dry matter, \% & 22.7 & 22.4 \\
\% of DM: & 6.2 & 7.4 \\
Ash & 15.3 & 14.9 \\
Crude protein & 6.0 & 6.5 \\
Crude fat & 33.0 & 32.2 \\
Crude fibre & 39.0 & 39.0 \\
N-free extract & 1.60 & 3.22 \\
Sugars as glucose & 8.18 & 7.59 \\
Lactic acid & 3.61 & 1.73 \\
Acetic acid & 0.37 & 0.06 \\
Propionic acid & + & + \\
Butyric acid & 0.17 & 0.14 \\
NH & 1.42 & 1.26 \\
Soluble N & 4.0 & 3.8 \\
pH & & \\
\hline
\end{tabular}


material and found that the residues in the mature silage were $38-100 \%$ of the orginal amount. BECK and GROSS (1973) found residues of less than $10 \%$ 3-4 weeks after preparation and $0.5-1 \%$ after 10 weeks, the average formaldehyde concentration in the silage samples being about $1 \mathrm{mg} / \mathrm{kg}$. In laboratory experiments no formaldehyde residues were found in Viher solution silage (KREULA and RAURAMAA 1977), whereas in farm silages the formaldehyde concentration in the autum samples averaged $120 \mathrm{mg} / \mathrm{kg}$ and in the spring samles $59 \mathrm{mg} / \mathrm{kg}$ (RAURAMAA and KREULA 1977).

It seems that the amounts of formaldehyde used in silage making, are actually so low that their effect in practical silage making is very difficult to determine. The same thing was observed when the protein-protective effect of formeldehyde-containing silage additives was studied. The results have varied: sometimes an effect could be demonstrated; sometimes no effect was found (BARRY and FENNESY 1972, SYRJÄLÄ 1972, 1975, ETTALA et al. 1975, MÜHLBACH and KAUFMANN 1979).

\section{Transfer of formaldehyde from feeds to milk}

The results of Exp. 2 showed that an increase in the amount of formaldehyde in the diet was accompanied by a rise in the formaldehyde content of the milk (Fig. 1-2, Table 2).

Table 2. Effect of the diet formaldehyde on the amount of formaldehyde excreted in the milk.

\begin{tabular}{ccc}
\hline $\begin{array}{c}\text { Supply level of HCHO } \\
\mathrm{mg} / \text { cow/ day }\end{array}$ & $\begin{array}{c}\text { Number of milk } \\
\text { samples }\end{array}$ & $\begin{array}{c}\text { Excretion of HCHO in milk, } \\
\mathrm{mg} / \mathrm{cow} / \mathrm{day}\end{array}$ \\
\hline$<\quad 1000$ & 10 & 2.9 \\
$1000-2000$ & 45 & 5.7 \\
$2000-3000$ & 13 & 10.2 \\
$>\quad 3000$ & 12 & 12.3 \\
\hline
\end{tabular}

Fig. 1. Effect of formaldehyde supply in silage on formaldehyde content

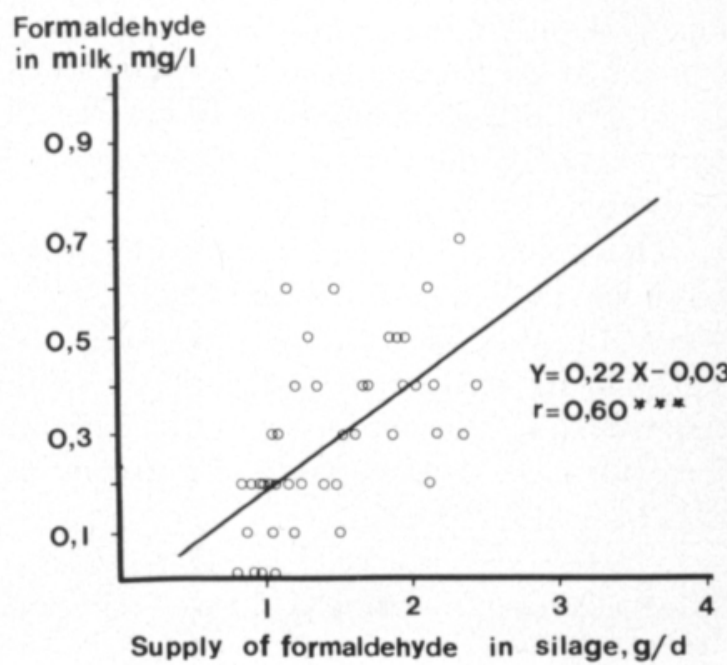




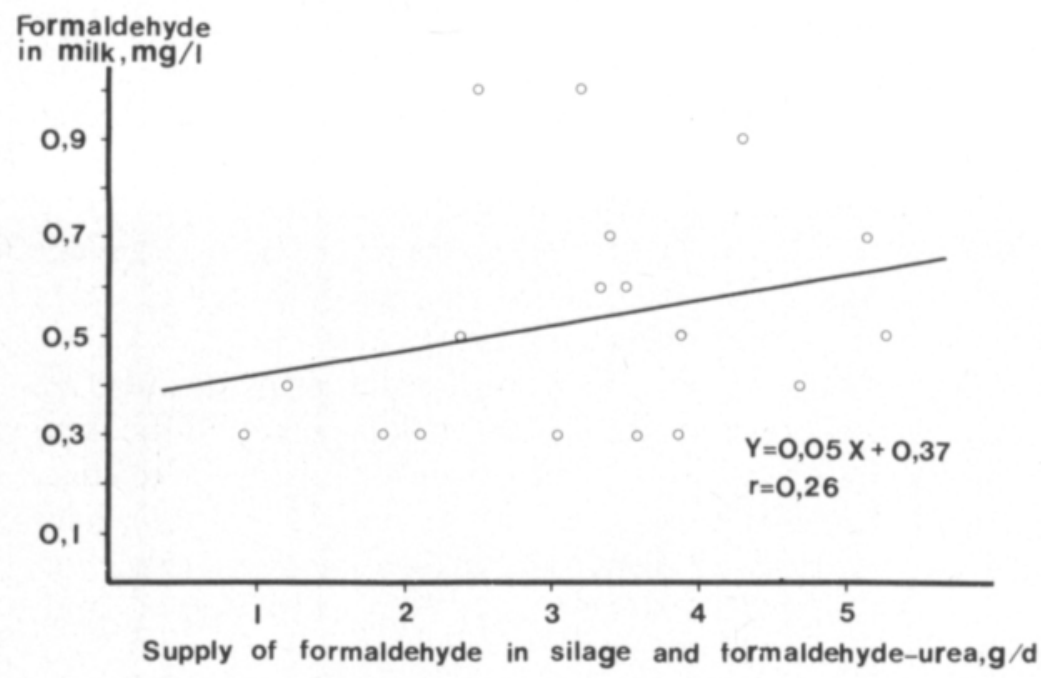

Fig. 2. Effect of formaldehyde supply in silage and formaldehyde-urea on formaldehyde content of milk.

When the only source of formaldehyde was silage, there was a significant positive correlation between the formaldehyde content of the diet and that of the milk $\left(\mathrm{Y}=0.22 \mathrm{X}-0.03, \mathrm{r}=0.60^{* * *}\right.$, Fig. 1$)$. When the cows also received formaldehyde from formaldehyde-urea, the correlation was not significant $(\mathrm{Y}=0.05 \mathrm{X}+0.37, \mathrm{r}=0.26$, Fig. 2). It thus appears that the transfer of formaldehyde to milk occurs more easily and more completely from silage than from formaldehyde-treated urea. This conclusion is supported by the results of Exp. 1, where formaldehyde was found in only a few milk samples. In Exp. 1 the main source of formaldehyde was formaldehyde-urea ( $94 \%$ ), the formaldehyde content of the silage being insignificant. The total formaldehyde supply of the cows on the formaldehyde-urea diets was, however, at the same level in Exp. 1 and Exp. 2: 2.14 and $2.87 \mathrm{~g} / \mathrm{cow} /$ day, respectively.

One reason for these results may be that the formaldehyde is rather tightly bound to the urea. This is supported by the fact that the formaldehyde content of the urea remained constant throughout the experiments.

It should also be mentioned here that there were large individual differences between the cows in the formaldehyde content of the milk. This was seen most clearly in Exp. 1.

The other studies concerning the formaldehyde content of milk have given varied results (BECK and GROSS 1973, KREULA and KAURAMAA 1976, WRENN et al. 1976, SYRJÄLÄ et al. 1978, SYRJÄLÄ-QVIST and SETÄLÄ 1982). This can be attributed to differences in the formaldehyde content of the ration and in the components of the rations that have been treated with formaldehyde. The methods of determining formaldehyde and their exactness have also varied.

Acknowledgements. - We wish to express our best thanks to the companies Valio, Farmos and Kemira for helping us to perform this study. 


\section{References}

ANON 1975. Association of Official Agricultural Chemists, Official Methods of analysis. 12 th Ed., Washington.

BARRY, T. N. \& FENNESY, P. F. 1972. The effect of formaldehyde treatment on the chemical composition and nutritive value of silage. NZJ. Agric. Res. 15: 712-722.

BECK, Th. \& GROSS, F. 1973. Zur Frage der Rückstande bei der Verwendung Formaldehydhaltiger Zusatzmittel bei der Gärfutterbereitung. Das Wirtschaftseigene Futter 19: 282-289.

ETTALA, E., POHJANHEIMO, O., HUIDA, L. \& LAMPILA, M. 1975. Ensilage of grass with acids and acid-formaldehyde additives I. Preservation and composition of silage. Ann. Agric. Fenn. 14: 286-303.

HONIG, H. \& ROHR, K. 1973. Über den Einfluss von Formalin und formalinhaltigen Zusatzmitteln auf der Silierverlauf und die Vormagenverdauung bei Milchkühen. Das Wirtschaftseigene Futter 19: 21-30.

KREULA, M. \& RAURAMAA, A. 1976. Transfer of formaldehyde from feed to milk during the feeding of fresh cut grass treated with formaldehyde-containing preservative. J. Scient. Agric. Soc. Finl. 48: 154-157.

- \& RAURAMAA, A. 1977. Formaldehyde and $\mathrm{HCOOH}$ in the ensiling process and the metabolism of dairy cows. Agrochimica 21: 341-355.

MÜHLBACH, P. R. F. \& KAUFMANN, W. 1979. Eiweiss-Verfügbarkeit von Formaldehyde-behandelter Grasssilage beim Wiederkäuer. Das Wirtschaftseigene Futter 2: 115-132.

RAURAMAA, A. \& KREULA, M. 1977. On the formaldehyde content of the silages prepared with formaldehyde-containing preservative. J. Scient. Agric. Soc. Finl. 49: 199-202.

SETÄLÄ, J. \& SYRJÄLÄ-QVIST, L. 1982 a. The degradation and utilization of formaldehyde-treated urea by rumen microbes in vitro. J. Scient. Agric. Soc. Finl. 54: 15-24.

- \& SYRJÄLÄ-QVIST, L. 1982 b. Effect of the crude protein level on the utilization of untreated and formaldehyde-treated urea in vitro. J. Scient. Agric. Soc. Finl. 54: 25-31.

- \& SYRJÄLÄ-QVIST, L. 1982 c. Effect of formaldehyde-treated urea on rumen fermentation, ration digestibility and nitrogen utilization. J. Scient. Agric. Soc. Finl. 54: 33-42.

— \& SYRJÄLÄ-QVIST, L. 1982 d. Formaldehyde-treated urea as a N-source for lactating dairy cows. J. Scient. Agric. Soc. Finl. 54: -

— , SYRJÄLÄ-QVIST, L., POUTIAINEN, E. \& TUORI, M. 1982. Unpublished.

SYRJÄLÄ, L. 1972. Effect of different sucrose, starch and cellulose supplements on the utilization of grass silage by ruminants. Ann. Agric. Fenn. 11: 199-276.

- 1975. Live-weight gain, feed intake and wool growth of lambs on different grass silages and sucrose and starch supplements. Ann. Agric. Fenn. 14: 338-348.

— , POUTIAINEN, E. \& KOSKELA, V.-H. 1978. Untreated and formaldehyde treated skimmilk powder as a protein supplement for dairy cows. J. Scient. Agric. Soc. Finl. 50: 155-165.

SYRJÄLÄ-QVIST, L. \& SETÄLÄ, J. 1982. Formaldehyde content of milk. 1. Cows fed on protein concentrates treated with different amounts of formaldehyde. J. Scient. Agric. Soc. Finl. 54: 63-67.

WRENN, T. R., WEYANT, J. R., WOOD, D. L. \& BITMAN, J. 1976. Increasing polyunsaturation of milk fats by feeding formaldehyde protected sunflower-soybean supplement. J. Dairy Sci. 59: 627-635.

Ms received March 24, 1982 


\title{
Maidon formaldehydipitoisuus. 2. Lehmät saivat formaldehydiä sisältä- vällä säilöntäaineella säilöttyä nurmirehua ja formaldehydillä käsiteltyä urea.
}

\author{
Liisa Syrjälä-Qvist ja Jouko Setälä \\ Helsingin yliopiston kotieläintieteen laitos, 00710 Helsinki 71
}

Kahdessa eri tutkimuksessa selvitettiin sekä säilörehujen formaldehydipitoisuutta, kun ne oli valmistettu formaldehydiä sisältävällä säilöntäaineella, että maidon formaldehydipitoisuutta lehmien saadessa ko. säilörehuja ja formaldehydillä käsiteltyä ureaa. Molemmissa kokeissa säilörehut oli valmistettu Viherliuoksella, 5 l/1000 kg ruohoa. Kokeen 1 säilörehu oli lievästi esikuivattua $(23 \% \mathrm{ka})$ ja kokeen 2 tuoreena säilöttyä $(22 \% \mathrm{ka})$. Urean käsittelytaso oli $1.4-1.5 \mathrm{~g}$ formaldehydiä/100 g ureaa. Kokeessa 1 oli $22 \mathrm{Fr}$ lehmää ja kokeessa 220 Ay-lehmää jaettuina kahteen ryhmään, joista toiset ryhmät saivat säilörehun lisäksi myös formaldehydillä käsiteltyä ureaa. Koe 1 kesti 18 viikkoa ja koe 213 viikkoa. Keskimääräinen maitotuotos kokeessa 1 oli $14.2 \mathrm{~kg}$ ja kokeessa $222.8 \mathrm{~kg} 4 \%$ :ista maitoa.

Kokeiden alkaessa vähintään 4 kk oli kulunut säilörehujen valmistamisesta. Kokeen 1 säilörehu sisälsi keskimäärin $13 \mathrm{mg}$ formaldehydiä $/ \mathrm{kg}(10-16 \mathrm{mg} / \mathrm{kg}, \mathrm{n}=5)$ ja kokeen 2 säilörehu vastaavasti $64 \mathrm{mg} / \mathrm{kg}$ $(45-90 \mathrm{mg} / \mathrm{kg}, \mathrm{n}=8)$. Molemmat säilörehut olivat käymiskriteerein arvosteltaessa hyvälaatuisia. Aistinvaraisen arvostelun mukaan kokeen 2 säilörehu sensijaan oli heikompilaatuista kuin kokeen 1 säilörehu.

Kokeessa 1 lehmät saivat formaldehydiä säilörehusta keskimäärin $0.13 \mathrm{~g} / \mathrm{pv}$ ja käsiteltyä ureaa saaneessa ryhmässä lisäksi $2.01 \mathrm{~g} / \mathrm{pv}$ (yhteensä $2.14 \mathrm{~g} / \mathrm{pv}$ ). Viimeksi mainitussa ryhmässä, jossa siis päasaiallinen formaldehydin lähde oli formaldehydillä käsiteltyä ureaa $(94 \%)$, vain neljän lehmän maidossa tavattiin formaldehydiä eikä tällöinkään edes jokaisena viitenä näytteenottokertana, vaan kolmella lehmällä kerran ja yhdellä kaksi kertaa. Formaldehydipitoisuus oli tuolloin $0.2-0.3 \mathrm{mg} / 1$ maitoa. Käsittelemätöntä ureaa saaneiden lehmien maidosta ei tavattu formaldehydiä ollenkaan.

Kokeessa 2 lehmät saivat eri ryhmissä formaldehydiä säilörehusta keskimäärin $1.47 \mathrm{~g} \mathrm{ja} 1.58 \mathrm{~g} / \mathrm{pv}$. Jälkimmäinen ryhmä sai lisäksi käsitellystä ureasta formaldehydiä keskimärin $1.29 \mathrm{~g} / \mathrm{pv}$ (yhteensä $2.87 \mathrm{~g}$ ) pv). Säilörehun ollessa ainoana formaldehydin lähteenä maidon formaldehydipitoisuus oli keskimäärin 0.3 $\mathrm{mg} / 1(0-0.7 \mathrm{mg} / \mathrm{l})$. Lehmien saadessa formaldehydiä sekä säilörehusta $(55 \%)$ että formaldehydillä käsitellystä ureasta (45 \%), maidon keskimääräinen formaldehydipitoisuus oli $0.6 \mathrm{mg} / 1(0.3-1.0 \mathrm{mg} / \mathrm{l})$.

Kun formaldehydin lähteenä kokeessa 2 oli vain säilörehu, oli rehuannoksen ja maidon formaldehydipitoisuuden välillä erittäin merkitsevä positiivinen korrelaatio, kun taas lehmän saadessa formaldehydiä sekä säilörehusta että formaldehydillä käsitellystä ureasta, ei vastaava korrelaatio ollut merkitsevä. Tämän perusteella näyttäisi siltä, että formaldehydiä siirtyisi maitoon helpommin säilörehusta kuin formaldehydillä käsitellystä ureasta. 